\title{
PENGARUH TINGKAT KOMPETENSI TERHADAP KINERJA PEGAWAI ADMINISTRASI PERKANTORAN
}

\author{
Lucia Nurbani Kartika \\ Fakultas Bisnis, Universitas Kristen Duta Wacana \\ ciakartika@yahoo.com
}

Agus Sugiarto

Fakultas Ekonomika dan Bisnis, Universitas Kristen Satya Wacana agus.sugiarto@staff.uksw.edu

\begin{abstract}
One big concern towards staff competency level is by doing a comprehensive research, every organization should know how its real staff competency level, its related factor, and also the impact of competency level towards staff performance. In this research result, the variable of education background does not affect the competency level. Meanwhile working experience variable has positive relationship towards competency level. Moreover, it is proven that there is a significant difference in competency level between staffs who have ever joined trainings and those who have never joined trainings. While staffs who have office administrative and secretarial education background have better competency level compared to those who do not have similar education background. The research result shows that office administrative staff's competency significantly affects staffs' performance. This research is expected to be able to give exact description on how far the staff competency level of Satya Wacana Christian University administrative staffs, also to identify the related factors towards staff competency level and its relationship with their working performance. The result is expected to give contributions to human resources management of Satya Wacana Christian University (UKSW) in developing and improving the human resources quality especially administrative staff of UKSW.
\end{abstract}

Keywords: Competency, Performance

\section{PENDAHULUAN}

Organisasi akan berkembang dan mampu bertahan dalam lingkungan persaingan yang kompetitif apabila didukung oleh pegawai-pegawai yang berkompeten di bidangnya. Pegawai merupakan aset organisasi yang vital karena memberi kontribusi besar sebagai penggerak roda organisasi dan aktor yang menjalankan tujuan organisasi. Dalam pelayanan administrasi perkantoran, pegawai 
merupakan tulang punggung (back office supports), sehingga di dalam lingkungan persaingan yang kompetitif ini layanan yang cepat dan tepat tidak dapat ditawar lagi. Dengan demikian isu tentang kompetensi dan kinerja pegawai menjadi hal yang penting dan menarik dalam upaya pengelolaan sumber daya manusia dalam sebuah organisasi. Salah satu perhatian kepada tingkat kompetensi pegawai adalah dengan melakukan penelitian secara komprehensif sehingga setiap organisasi mengetahui seberapa tingkat kompetensi pegawai yang sesunggguhnya, faktor-faktor yang memengaruhi, serta dampak tingkat kompetensi terhadap kinerja pegawai.

Dewasa ini konsep kinerja sering dikaitkan dengan konsep kompetensi. Dengan demikian kedua konsep ini menjadi populer pada saat ini. Banyak organisasi bisnis dan non bisnis sangat memperhatikan hal ini dengan penerapan konsep kinerja berdasarkan kompetensi karyawan. PT Indosat Tbk menerapkan konsep CBHRM (Competency Based Human Resources Management) dengan manfaat efisiensi dan efektivitas SDM meningkat. KonsepTalent Management dan Competency Based HRM juga diterapkan oleh PT Dharma Polimetal Tbk. Sedangkan beberapa konsep kompetensi dan kinerja lain juga diaplikasikan pada PT Astra International Tbk dengan program Action Learning Concept, Leadership Competence Development, Functional Competence Development. Hal tersebut menunjukkan bahwa konsep kinerja dan kompetensi menjadi hal yang penting dan menarik untuk dikaji.

Berdasarkan Perpen No. 23 tahun 2004 telah dibentuk Badan Nasional Sertifikasi Profesi (BNSP) yang merupakan badan independen dan bertanggung jawab langsung kepada Presiden dengan tugas menyelenggarakan sertifikasi profesi melalui uji kompetensi. Pembukaan BNSP juga sesuai dengan UU No.13 tahun 2003 tentang ketenagakerjaan, pasal 18 ayat 4 dan ayat 5. Keputusan Menteri Tenaga Kerja dan Transmigrasi Kep 195/MEN/IV/2007 tentang Penetapatan Standar Kompetensi Kerja Nasional Indonesia (SKKNI)sektor jasa perusahaan sub sektor jasa perusahaan lainnya bidang jasa administrasi perkantoran. Perpen, undang-undang dan Keputusan Menteri di atas juga sebagai pendorong tersedianya Sumber Daya Manusia yang berkompeten di bidangnya dan sebagai faktor pendorong pengukuran kinerja berdasarkan kompetensi.

Model kompetensi profesional yang holistik adalah model yang dipakai sebagai prediktor kinerja pegawai Universitas Kristen Satya Wacana (UKSW) dalam penelitian ini. Model ini dikemukakan oleh Chetham dan Chivers (1996), yang membagi kompetensi empat kompetensi inti yang membentuk kompetensi profesional yaitu: (1) pengetahuan/kompetensi kognitif, yaitu penguasaan secara benar pengetahuan yang berkaitan dengan kerja sehingga dapat dimanfaatkan untuk meningkatkan efektifitas dalam bekerja,(2) kompetensi fungsional, merupakan kemampuan untuk melaksanakan tugas-tugas yang berkaitan dengan kerja secara efektif sehingga memberikan hasil yang optimal, (3) kompetensi perilaku individu, merupakan kemampuan untuk mengadopsi perilaku yang baik sesuai dengan situasi yang berkaitan dengan kerjadan (4) kompetensi nilai dan etika, adalah penguasaan 
nilai-nilai profesional dan pribadi yang benar sehingga dapat meningkatkan kemampuan dalam membuat penilaian yang benar dalam situasi kerja (Suharti 2005).

Profesi sebagai pegawai administrasi perkantoran di UKSW dilakukan oleh banyak orang dari berbagai latar belakang pendidikan dengan demikian dapat menimbulkan pertanyaan dan keraguan akan kompetensi yang dimilikinya. Kemajuan perekonomian dan teknologi dalam era globalisasi semakin menuntut tersedianya Sumber Daya Manusia (SDM) yang berkualitas dan kompeten di segala sektor usaha, agar mampu menghadapi persaingan yang semakin tajam menyebabkan perlunya peningkatan kemampuan SDM agar diakui memiliki kompetensi pada bidangnya. UKSW merupakan lembaga pendidikan tinggi yang memiliki cukup banyak pegawai, baik pegawai akademik maupun non akademik. Salah satu bagian dari pegawai non akademik adalah pegawai bagian administrasi yang tersebar di berbagai unit kerja. Berdasarkan pengamatan awal nampak bahwa fenomena-fenomena yang terkait dengan adanya permasalahan dalam kinerja pegawai. Banyaknya pegawai yang kesulitan dalam pembuatan naskah surat, baik dalam bahasa Indonesia maupun dalam bahasa Inggris. Selain itu beberapa pegawai nampak kesulitan dalam pengelolaan arsip, sehingga sering terjadi keluhan dalam pencarian arsip di kantor. Fenomena yang lain yaitu adanya beberapa keluhan dari mahasiswa atas pelayanan kantor di beberapaunit kerja.Nampak juga pegawai administrasibelum menguasai pengoperasian/pemanfaatankomputer dan aplikasi perkantoran secara optimal.

Dengan melihat latar belakang tersebut, maka peneliti tertarik untuk melakukan pengkajian tentang tingkat kompetensi para pegawai administrasi di UKSW, serta pengaruhnya terhadap kinerja mereka. Permasalahan utama dari penelitian ini adalah pengaruh kompetensi terhadap kinerja pegawai administrasi perkantoran pada UKSW. Sedangkan kompetensi juga berhubungan dengan beberapa hal, yaitu jenjang pendidikan, pengalaman kerja, bidang pendidikan dan program pelatihan. Dari permasalahan utama, maka rumusan persoalan dalam penelitian ini adalah: (1) apakah terdapat hubungan antara jenjang pendidikan formal dengan kompetensi pegawai administrasi perkantoran pada Universitas Kristen Satya Wacana? (2) Apakah terdapat hubungan antara pengalaman kerja dengan kompetensi pegawai administrasi perkantoran pada Universitas Kristen Satya Wacana? (3) Apakah terdapat perbedaan kompetensi pegawai administrasi perkantoran dengan latar belakang pendidikan bidang studi administrasi perkantoran/kesekretarisan dengan non administrasi perkantoran/kesekretarisan? (4) Apakah terdapat perbedaan kompetensi pegawai administrasi perkantoran dalam kategori keterlibatan pelatihan/training? dan (5) apakah terdapat pengaruh kompetensi yang dimiliki pegawai administrasi perkantoran pada Universitas Kristen Satya Wacana terhadap kinerja mereka? 


\section{TINJAUAN PUSTAKA Kompetensi}

Menurut Standar Kompetensi Kerja Nasional Indonesia (SKKNI) Sektor Jasa Bidang Jasa Administrasi Perkantoran (2007), kompetensi kerja merupakan kemampuan kerja setiap individu yang mencangkup aspek pengetahuan, keterampilan dan sikap kerja yang sesuai dengan standar yang ditetapkan. Standar Kompetensi Kerja Nasional Indonesia adalah rumusan kemampuan kerja yang mencangkup aspek pengetahuan, keterampilan dan atau keahlian sikap kerja yang relevan dengan pelaksanaan tugas dan syarat jabatan yang ditetapkan sesuai dengan ketentuan peraturan perundang-undangan yang berlaku. Sementara tugas-tugas yang berhubungan dengan administrasi perkantoran-perkantoran diantaranya melakukan fungsi resepsionis dan menjalankan tugas-tugas administrasi perkantoran seperti membuat naskah sederhana, lembar kerja dan bahan presentasi melalui pemakaian software yang sesuai, menerima dan meneruskan telepon masuk kepada yang dituju, menggunakan peralatan kantor seperti faksimili, mesin fotokopi dan lain-lain, menerima dan meneruskan surat atau dokumen kepada yang dituju, menerima dan mengantar tamu, pengarsipan dan memasukkan data dalam lingkup dan konteks yang terbatas di bawah pengawasan langsung dan sesuai arahan atasannya.

Dari berbagai literatur yang merupakan hasil kajian empirik maupun konseptual, definisi tentang kompetensi secara umum dapat dilihat dari dua perspektif. Perspektif yang pertama menggambarkan kompetensi dari sudut pandang organisasi, yang mana kompetensi digambarkan sebagai pengetahuan, kepakaran dan kemampuan suatu organisasi yang dapat menjadikan organisasi tersebut memiliki keunggulan dibandingkan dengan para pesaingnya. Pengertian kompetensi dalam hal ini terkonsentrasi pada kompetensi suatu organisasi sebagai suatu kesatuan dan menyeluruh. Sedangkan perspektif kedua mengarah pada kompetensi yang dimiliki individu. Dalam konteks ini, kompetensi diartikan sebagai karakteristik-karakteristik yang dapat diidentifikasi dari seseorang yang melakukan pekerjaannya secara efektif. Karakteristik tersebut dapat meliputi motif, sifat, keterampilan, citra diri, peranan sosial dan pengetahuan yang dimiliki.Williams dalam Carters (2011) mengemukakan bahwa individual competence describes what a person is capable of doing and includes a combination of motives and traits, the self-image of a person and his or her social role, skills and knowledge. Dari pendapat tersebut, nampak bahwa kompetensi individual dapat dilihat dari kemampuan seseorang untuk melakukan sesuatu pekerjaan dan termasuk didalamnya kombinasi motivasi dan sifatnya, citra diri atau peran sosialnya, keahlian dan pengetahuan.

Berdasarkan uraian tersebut makna kompetensi mengandung bagian kepribadian yang mendalam dan melekat pada seseorang dengan perilaku yang dapat diprediksi pada berbagai keadaan dan tugas pekerjaan. Prediksi siapa yang berkinerja baik dan kurang baik dapat diukur dari kriteria atau standar yang digunakan. Analisis 
kompetensi disusun sebagian besar untuk pengembangan karier, tetapi penentuan tingkat kompetensi dibutuhkan untuk mengetahui efektivitas tingkat kinerja yang diharapkan. Menurut Boulter et al. (1996), level kompetensi adalah sebagai berikut:skill, knowledge, social role, self image, trait dan motive. Skill adalah kemampuan untuk melaksanakan suatu tugas dengan baik. Knowledge adalah informasi yang dimiliki seseorang untuk bidang khusus/tertentu. Social role adalah sikap dan nilai-nilai yang dimiliki seseorang dan ditonjolkan dalam masyarakat (ekspresi nilai-nilai diri). Self image adalah pandangan orang terhadap diri sendiri, merekflesikan identitas. Trait adalah karakteristik abadi dari seorang karakteristik yang membuat orang untuk berperilaku.Motive adalah sesuatu dorongan seseorang secara konsisten berperilaku, sebab perilaku seperti hal tersebut sebagai sumber kenyamanan.

Menurut Robotham dan Jubb (1996), Kompetensi juga dapat diartikan sebagai perilaku dari seseorang, dalam bereaksi dan memberi respon terhadap pekerjaannya di dalam lingkup organisasi. Pendapat yang lebih singkat diungkapkan Armstrong (1998),bahwa kompetensi adalah pengetahuan, ketrampilan dan kualitas individu untuk mencapai kesuksesan pekerjaannya (Suharti 2005). Lebih lanjut, dalam keputusan Menteri Pendidikan Nasional No.45/U/2002, menyebutkan kompetensi merupakan seperangkat tindakan cerdas, penuh tanggungjawab yang dimiliki seseorang sebagai syarat untuk dianggap mampu oleh masyarakat dalam melaksanakan tugas-tugas di bidang pekerjaan tertentu. Sedangkan elemen-elemen kompetensi terdiri atas landasan kepribadian, penguasaan ilmu dan keterampilan, kemampuan berkarya, sikap dan perilaku dalam berkarya menurut tingkat keahlian, berdasarkan ilmu dan keterampilan yang dikuasai, serta pemahaman kaidah berkehidupan bermasyarakat sesuai dengan pilihan keahlian dalam berkarya.

Pengertian kompetensi dalam kenyataannya belum ada kesepakatan universal dan beberapa pakar memberikan pengertian yang cukup bervariasi. Namun secara umum isitilah kompetensi sumber daya manusia dapat disimpulkan sebagai capability to perform. Kesimpulan ini mengindikasikan bahwa kompetensi sumber daya manusia terdiri berbagai variabel. Sanchez (1997) menegaskan bahwa kompetensi dapat dibedakan menjadi dua, yaitu yang bersifat visible, seperti kompetensi pengetahuan (knowledge competency) dan kompetensi keahlian (skill competency) serta kompetensi yang bersifat invisible (hidden competency) seperti konsep diri, sifat dan motif yang semuanya dapat dikategorikan dalam variabel sikap (attitude). Sementara itu Robbins (2001) mengemukakan bahwa salah satu bentuk kompetensi yang merupakan biographical characteristic adalah kemampuan (ability) yang terdiri dari intellectual ability dan physical ability.

Jadi secara komprehensif kompetensi memiliki empat variabel yaitu (1) pengetahuan (knowledge), (2) keahlian (skill), (3) kemampuan (ability) dan (4) sikap (attitude). Keempat variabeltersebut diintegrasikan dalam sebuah model untuk mengimplemantasikan keempat variabel kompetensi secara efektif dan efisien (Tandelilin2004). 
Menurut Palan (2007) kompetensi sering dikenal sebagai kecakapan dan keberdayaan merujuk pada keadaan atau kualitas mampu dan sesuai. Definisi kompetensi di tempat kerja merujuk pada pengertian kecocokan seseorang dengan pekerjaanya. Kompetensi merujuk kepada karakteristik yang mendasari perilaku yang menggambarkan motif, karakteristik pribadi, konsep diri, nilai-nilai, pengetahuan atau keahlian yang dibawa seseorang yang berkinerja unggul di tempat kerja. Kompetensi terdiri dari beberapa jenis karakteristik yang berbeda, yang mendorong perilaku. Fondasi karakteristik ini terbukti dalam cara seseorang berperilaku di tempat kerja. Kompetensi adalah mengenai orang seperti apa dan apa yang dapat mereka lakukan, bukan apa yang mungkin mereka lakukan. Kompetensi dapat didefinisikan sebagai karakteristik dasar seseorang yang memiliki hubungan kausal dan kriteria referensi efektivitas dan atau keunggulan dalam pekerjaan atau situasi tertentu. Kompetensi merupakan karakter dasar orang yang mengindikasikan cara berperilaku atau berpikir yang berlaku dalam cakupan situasi yang sangat luas dan bertahan untuk waktu yang lama.

Pada era globalisasi dewasa ini, kompetensi bukan sekedar pengetahuan dan keterampilan. Kompetensi merupakan kemampuan khusus yang sangat kompleks. Dari vademikum pekerjaan yang disusun oleh Departemen Tenaga Kerja berbagai negara, terdapat ribuan kompetensi mulai dari kompetensi dokter, guru, tentara dan polisi. Jika kompetensi, sikap dan tindakan pegawai terhadap pekerjaannya tinggi, maka dapat diprediksi bahwa perilakunya akan bekerja keras untuk mencapai tujuan organisasi, tentunya jika faktor-faktor yang diuraikan pada gambar di atas tidak menghambat perilaku kerja pegawai. Oleh karena itu, kompetensi dijadikan dasar dalam mengevaluasi kinerja pegawai yang disebut evaluasi berdasarkan kompetensi (Competency Based Performance Appraisal) oleh sejumlah organisasi. Misalnya, kompetensi di Jepang digunakan sebagai dasar evaluasi kinerja dengan menguji kompetensi pegawai secara periodik. Jika kompetensinya meningkat, maka pangkat dan gajinya akan meningkat. Untuk meningkatkan kompetensi, suatu organisasi merancang dan melaksanakan program pengembangan SDM.

\section{Kinerja}

Kinerja adalah hasil kerja yang dapat dicapai oleh seseorang atau sekelompok orang dalam suatu organisasi sesuai dengan wewenang dan tangung jawab masing-masing, dalam rangka upaya mencapai tujuan organisai bersangkutan secara legal, tidak melanggar hukum dan sesuai dengan moral dan etika (Prawirosentono 1999). Pengertian kinerja atau prestasi kerja diberi batasan oleh Maier dalam As'ad (1995) sebagai kesuksesan seseorang di dalam melaksanakan suatu pekerjaan. Lebih tegas lagi Lawler dan Poter juga (dalam As'ad 1995) menyatakan bahwa kinerja adalah succesfull role achievement yang diperoleh seseorang dari perbuatannya, sedang Suprihanto (2003) mengatakan bahwa kinerja atau prestasi kerja seorang karyawan pada dasarnya adalah hasil kerja seseorang karyawan selama periode tertentu dibandingkan dengan kemungkinan, misalnya 
standar, target/sasaran atau kinerja yang telah ditentukan terlebih dahulu dan telah di sepakati bersama.Kinerja karyawan lebih mengarah pada tingkatan prestasi kerja karyawan.

Sehubungan dengan konsep kinerja, Simanjuntak (2005) mengatakan bahwa kinerja adalah tingkat pencapaian hasil atas pelaksanaan tugas tertentu. Kinerja individu atau kinerja karyawan merefleksikan bagaimana karyawan memenuhi keperluan pekerjaan dengan baik. Mathis dan Jackson (2006), mendefinisikan bahwa kinerja pada dasarnya adalah apa yang dilakukan dan tidak dilakukan karyawan. Kinerja karyawan adalah yang memengaruhi seberapa banyak mereka memberikan kontribusi kepada organisasi yang antara lain termasuk: (1) kuantitas keluaran, (2)kualitas keluaran, (3)jangka waktu keluaran, (4)kehadiran di tempat kerja, (5)sikap kooperatif. Sumber daya manusia sebagai aktor yang berperan aktif dalam menggerakkan perusahaan/organisasi dalam mencapai tujuannya.

Menurut Wirawan (2009), konsep kinerja merupakan singkatan dari kinetika energi kerja. Kinerja adalah luaran yang dihasilkan oleh fungsi-fungsi atau indikatorindikator suatu pekerjaan atau suatu profesi dalam waktu tertentu. Kinerja merupakan hasil sinergi dari sejumlah faktor. Faktor-faktor tersebut adalah faktor lingkungan organisasi, faktor lingkungan eksternal dan faktor internal pegawai. Kinerja pegawai merupakan hasil sinergi dari sejumlah faktor. Faktor-faktor tersebut adalah faktor lingkungan internal organisasi, faktor lingkungan eksternal dan faktor internal karyawan atau pegawai.

\section{Bagaimana kompetensi terkait dengan kinerja?}

Menurut Palan (2007) kompetensi adalah enabler. Diharapkan seseorang yang kompeten agar mampu memberikan hasil yang diharapkan sesuai standar organisasi baik dari segi kualitas, kuantitas, maupun biaya. Meskipun demikian, tidak selalu kompetensi akan menghasilkan kinerja sesuai standar organisasi, karena tuntutan pekerjaan dan lingkungan organisasi juga faktor yang memengaruhioutput. Apabila ketiga unsur kompetensi, tuntutan pekerjaan dan lingkungan organisasi tidak selaras, kompetensi saja tidak dapat memastikan hasil.

Sementara menurut Wirawan (2009), kinerja mempunyai hubungan kausal dengan kompetensi. Kinerja merupakan fungsi dari kompetensi, sikap dan tindakan. Kompetensi melukiskan karakteristik pengetahuan, keterampilan, perilaku dan pengalaman untuk melakukan suatu pekerjaan atau peran tertentu secara efektif. Pengetahuan melukiskan apa yang terdapat dalam kepala seseorang, mengetahui kesadaran atau pemahaman mengenai sesuatu, misalnya pemahaman mengenai pekerjaan. Keterampilan melukiskan kemampuan yang dapat diukur yang telah dikembangkan melalui praktik, pelatihan dan pengalaman. Kompetensi secara objektif dapat diukur dan dikembangkan melalui supervisi, manajemen kinerja dan program pengembangan SDM. Berdasarkan argumentasi dan hasil riset terdahulu, maka hipotesis penelitian sebagai berikut. 
$\mathbf{H}_{1}$ : Terdapat hubungan antara jenjang pendidikan formal dengan kompetensi pada pegawai administrasi perkantoran.

$\mathbf{H}_{2}$ : Terdapat hubungan antara pengalaman kerja dengan kompetensi pada pegawai administrasi perkantoran.

$\mathbf{H}_{3}$ : Terdapat perbedaan kompetensi antar pegawai administrasi perkantoran dalam kategori bidang pendidikan formal.

$\mathbf{H}_{4}$ : Terdapat perbedaan kompetensi antar pegawai administrasi perkantoran dalam kategori keterlibatan dalam pelatihan/training.

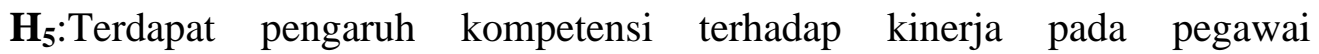
administrasi perkantoran.

\section{Model Penelitian}

Model penelitian Gambar 1 menunjukkan bahwa variabel tingkat/jenjang pendidikan dan pengalaman merupakan variabel bebas yang memengaruhi variabel terikat yaitu kompetensi. Untuk selanjutnya variabel kompetensi menjadi variabel bebas yang memengaruhi variabel terikat kinerja pegawai administrasi perkantoran. Sedangkan dua variabel yang berada di luar yang dihubungkan dengan garis putusputus merupakan variabel yang berfungsi untuk mengetahui perbedaan tingkatkompetensi berdasarkan kategori variabel bidang studi pendidikan dan keterlibatan dalam pelatihan/training.

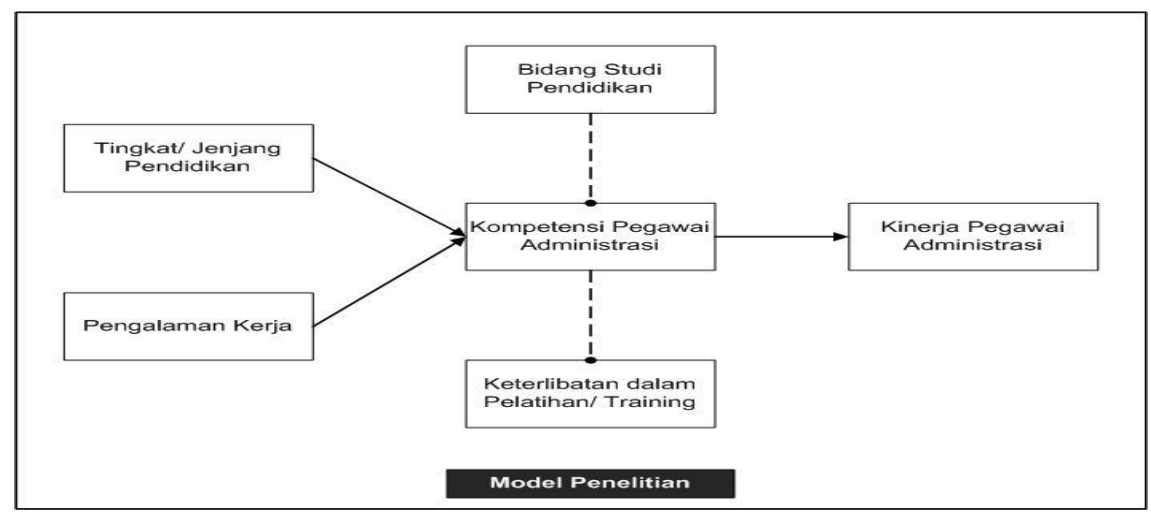

Gambar 1

Model Penelitian

\section{METODA PENELITIAN}

\section{Populasi dan Sampel}

Populasi dalam penelitian ini adalah seluruh pegawai administrasi perkantoran di UKSW Salatiga (86 orang) baik tetap maupun kontrak yang dipekerjakan pada unit-unit kerja. Metoda pengambilan sampel penelitian secara complete enumeration atau sensus, yaitu meliputi semua anggota populasi.Tugas kegiatan administrasi perkantoran adalah membuat naskah korespondensi/surat 
menyurat, membuat laporan, membuat lembar kerja dan bahan presentasi melalui pemakaian software yang sesuai, berkomunikasi (menerima dan meneruskan) telepon masuk kepada yang dituju, melakukan penggandaan dokumen, menggunakan peralatan kantor seperti komputer, faksimili, mesin fotokopi dan lain-lain, melaksanakan fungsi resepsionis, menerima dan mengantar tamu, menerima dan meneruskan surat/dokumen kepada yang dituju, pengarsipan, pengelolaan kas kecil (petty cash), pengolahan/memasukkan data dalam lingkup dan konteks yang terbatas di bawah pengawasan langsung dan sesuai arahan atasannya.

\section{Teknik Pengumpulan Data}

Pengisian kuesioner dilakukan oleh dua pihak, pihak pertama adalah pihak pimpinan langsung dari pegawai administrasi perkantoran. Kuesioner ini bertujuan untuk mendapatkan data tentang variabel kinerja para pegawai administrasi perkantoran. Sedangkan pihak yang kedua adalah para pegawai administrasi perkantoran, kuesioner ini bertujuan untuk memperoleh data tentang variabel kompetensi, bidang pendidikan formal, jenjang pendidikan formal, jumlah program pelatihan profesi, serta pengalaman kerja. Dengan demikian diharapkan data yang diperoleh lebih objektif.Dalam penelitian ini response rate sebesar 70 persen, yaitu jumlah 60 kuesioner dari responden yang telah diisi secara lengkap dari populasi penelitian yang berjumlah 86 orang.

\section{HASIL PENELITIAN DAN PEMBAHASAN}

\section{Variabel Penelitian}

Untuk tingkat pendidikan formal, dari 60 responden penelitian, 34 orang memiliki tingkat pendidikan formal Sekolah Menengah Umum/Sekolah Menengah Kejuruan atau sebesar 56,7 persen. 11 orang memiliki tingkat pendidikan formal tertinggi Program Diploma atau sebesar 18,3 persen dan 15 orang responden memiliki tingat pendidikan formal tertinggi Sarjana/S-1 atau sebesar 25 persen.

Dari pengalaman kerja, dapat digambarkan bahwa pengalaman kerja responden terendah adalah nol tahun, sedangkan pengalaman tertinggi adalah 33 tahun. Pelatihan/trainingdilihat melalui pernah atau tidaknya para responden keterlibatan pelatihan atau training yang berhubungan dengan profesi administrasi perkantoran kantor dalam tiga tahun terakhir. Hasil penelitian menunjukkan bahwa sebanyak 45 orang pegawai atau 75 persen tidak pernah mengikuti program pelatihan profesi dalam tiga tahun terakhir. Sedangkan sebanyak 15 orang telah mengikuti program pelatihan.

Dari bidang pendidikan formaldisesuaikan dengan profesi sebagai staf professional bidang administrasi perkantoran. Dalam hal ini dibedakan apakah para responden memiliki bidang studi formal administrasi perkantoran/kesekretarisan atau non administrasi perkantoran/kesekretarisan.Dari hasil penelitian menunjukkan bahwa responden yang memiliki bidang studi administrasi 
perkantoran/kesekretarisan sebanyak 19 responden atau sebesar 31,7 persen, sedangkan 41 responden atau 68,3 persen, tidak memiliki bidang studi pendidikan formal administrasi perkantoran/kesekretarisan.

Variabel kompetensi pegawai administrasi perkantorandiukur melalui beberapa indikator kompetensi. Dari hasil penelitian menunjukkan bahwa indikator kompetensi sikap/attitude memiliki rata-rata tertinggi yaitu sebesar 4,02 (dalam skala skor terendah satu dan tertinggi lima). Indikator kompetensi tingkat pengetahuan memiliki rata-rata 3,79. Sedangkan indikator kompetensi keterampilan teknis administrasi perkantoran dan kesekretariatan menjadi urutan terendah yaitu dengan rata-rata 3,56. Sedangkan secara umum, variabel kompetensi pegawai administrasi perkantoran memiliki rata-rata (mean) sebesar 3,79.

Variabel kinerja pegawai administrasi perkantoran diukur melalui beberapa indikator. Hasil penelitian dari 60 responden menunjukkan bahwa indikator perilaku kerja menempati urutan tertinggi dengan rata-rata skor 3,79 (dalam skala skor terendah satu dan tertinggi lima). Indikator hasil kerja memiliki rata-rata 3,76. Indikator teknis administrasi perkantoran memiliki rata-rata 3,71 sedangkan urutan terendah yaitu kepribadian dengan rata-rata 3,68. Sedangkan secara umum, variabel kinerja pegawai administrasi perkantoran memiliki rata-rata 3,74.

\section{HASIL PENELITIAN}

\section{Hasil Uji Validitas dan Reliabilitas}

Sebelum melakukan pengolahan data, diperlukan analisis uji validitas, realibilitas terhadap item-item pertanyaan dalam kuesioner, khususnya item pertanyaan variabel kompetensi pegawai administrasi perkantoran dan variabel kinerja pegawai administrasi perkantoran yang pengukurannya menggunakan skala likert. Dari hasil uji validasi, seluruh item pertanyaan dinyatakan valid. Sedangkan hasil uji reliabilitas dua variabelmenunjukkanalpha cronbach sebesar 0,955 dan 0,939 yang berarti sangat reliabel.

\section{Hasil Uji Hipotesis}

Uji hipotesis pertama dengan korelasi Kendall's Tau- $b$, menunjukkan angka 0,118 yang berarti korelasi yang sangat lemah. Angka probabilitas 0,248 $(>0,05)$, maka dapat diambil kesimpulan bahwa hubungan antara jenjang pendidikan dengan kompetensi adalah tidak signifikan.Uji Hipotesis kedua dengan korelasi pearson,menunjukkan bahwa output korelasi menunjukkan 0,304. Tingkat signifikansi (sig.(2-tailed))menunjukkan 0,018 $(<0,05)$ yang berarti mendukung hipotesis dua yaitu terdapat hubungan antara pengalaman kerja dengan kompetensi pegawai administrasi perkantoran.Uji Hipotesis 3 dengan Mann-Whitney Test diperoleh hasil bahwa nilai Zsebesar -3,933 dengan probabilitas (sig.) sebesar 0,000. Hal itu menunjukkan hipotesis tiga didukung, yang berarti terdapat perbedaan kompetensi pegawai administrasi perkantoran secara signifikan dalam kategori pegawai yang memiliki bidang studi administrasi perkantoran/kesekretarisan dan 
kategori pegawai tidak memiliki bidang studi administrasi perkantoran/kesekretarisan.Uji Hipotesis 4 denganMann-Whitney Test diperoleh hasil bahwa nilai $\mathrm{Z}$ sebesar $-4,976$ dengan probabilitas (sig.) sebesar 0,00. Hal itu menunjukkan hipotesis empat didukung, yang berarti terdapat perbedaan kompetensi pegawai administrasi perkantoran yang tidak pernah mengikuti pelatihan dan kategori pegawai yang pernah mengikuti pelatihan.Uji hipotesis 5 menunjukkan probabilitas $0,000 \quad(<0,05)$ kompetensi pegawai administrasi perkantoran berpengaruh secara signifikan terhadap kinerja pegawai administrasi perkantoran.

\section{PEMBAHASAN}

\section{Hubunganantara Jenjang Pendidikan Formal dengan Kompetensi Pegawai Administrasi Perkantoran}

Jenjang pendidikan formal merupakan pendidikan formal tertinggi yang dimiliki oleh pegawai administrasi perkantoran pada UKSW. Dari deskripsi pendidikan formal, nampak 34 orang memiliki tingkat pendidikan formal Sekolah Menengah Umum/Sekolah Menengah Kejuruan atau sebesar 56,7 persen. 11 orang memiliki tingkat pendidikan formal tertinggi Program Diploma atau sebesar 18,3 persen dan 15 orang responden memiliki tingat pendidikan formal tertinggi Sarjana/S-1 atau sebesar 25 persen. Dengan kata lain dapat dikatakan bahwa sebagian besar pegawai administrasi perkantoran memiliki jenjang pendidikan formal kategori SMU/SMK, yaitu sebesar 56,7 persen.

Banyak pendapat yang mengemukakan bahwa tingkat pendidikan formal merupakan faktor yang menentukan tingkat kompetensi seseorang. Dengan kata lain, bahwa kompetensi seseorang dapat diperoleh dan ditingkatkan melalui proses pendidikan. Pendidikan formal disebut sebagai salah satu faktor individu penting yang memengaruhi tingkat kompetensi seseorang. Simanjuntak (2005) mengungkapkan bahwa kemampuan dan keterampilan kerja setiap orang dipengaruhi oleh kebugaran fisik dan kesehatan jiwa individu yang bersangkutan, pendidikan, akumulasi pelatihan dan pengalaman kerjanya. Namun hasil uji hipotesis dalam penelitian ini menunjukkan bahwa hubungan antara jenjang pendidikan dengan kompetensi adalah tidak signifikan pada taraf kepercayaan 95 persen. Hal itu menunjukkan bahwa jenjang pendidikan formal para pegawai administrasi di UKSW tidak memiliki hubungan yang signifikan terhadap tingkat kompetensi kerja mereka.

\section{Hubungan Pengalaman Kerja dengan Kompetensi Pegawai Administrasi Perkantoran}

Faktor lain yang terbukti memengaruhi kompetensi pegawai administrasi perkantoran adalah pengalaman kerja.Penelitian ini turut mendukung pendapat yang telah dikemukakan oleh beberapa pihak tentang pengaruh pengalaman kerja terhadap kompetensi mereka. Simanjuntak (2005) mengungkapkan bahwa selain pendidikan formal, hal yang berkaitan dengan tingkat kompetensi adalah pengalaman kerja. 
Pengalaman kerja dapat memperdalam dan memperluas kemampuan kerja. Semakin sering seseorang melakukan pekerjaan yang sama, semakin terampil dan semakin cepat dia menyelesaikan pekerjaan tersebut. Semakin banyak macam pekerjaan yang dilakukan seseorang, pengalaman kerjanya semakin kaya dan luas dan memungkinkan peningkatan kinerjanya. Dengan kata lain, dengan pengalaman kerja seseorang akan mendapatkan pengembangan kompetensi yang sangat diperlukan dalam pekerjaannya. Backer dalam Suharti (2005) mengemukakan kompetensi seseorang dapat ditingkatkan selain melalui pendidikan formal, juga melalui pengalaman yang diperoleh.

Pengalaman kerja merupakan lama seseorang melakukan suatu pekerjaan tertentu. Melalui pengalaman yang ada seseorang dimungkinkan memiliki keterampilan dan keahlian yang semakin baik dalam melaksanakan tugasnya. Dengan kata lain, dengan pengalaman kerja pegawai administrasi perkantoran akan mendapatkan pengembangan kompetensi yang sangat diperlukan dalam pekerjaannya, yang akhirnya dapat meningkatkan kinerja.

Dari hasil uji hipotesis dalam penelitian ini menunjukkan bahwa terdapat hubungan antara pengalaman kerja dengan kompetensi pegawai administrasi perkantoran. Dengan demikian dapat dikatakan bahwa terdapat kecenderungan semakin tinggi pengalaman kerja akan semakin tinggi pula tingkat kompetensi para pegawai administrasi perkantoran di UKSW.

\section{Perbedaan Kompetensi Pegawai Administrasi Perkantoran dalam Kategori Bidang Pendidikan Formal}

Bidang pendidikan formal merupakan bidang/program studi pendidikan formal yang pernah diikuti oleh para pegawai administrasi perkantoran. Bidang studi dalam sebuah proses pendidikan memiliki capaian suatu kompetensi tertentu.Dengan kata lain suatu bidang studi akan menciptakan dan membentuk peserta didik agar memiliki kompetensi tertentu. Konsep link dan match antara program studi pendidikan dengan dunia kerja atau profesi tentunya akan sangat membantu kinerja. Kesesuaian antara proses pendidikan dengan tugas pekerjaan dalam suatu profesi tentunya sangat dibutuhkan.

Hasil penelitian menunjukkan bahwa pegawai administrasi yang memiliki bidang studi administrasi perkantoran/kesekretarisan sebanyak 19 responden atau sebesar 31,7 persen, sedangkan 41 responden atau 68,3 persen, tidak memiliki bidang studi pendidikan formal administrasi perkantoran/kesekretarisan. Dari deskripsi itu bisa dikatakan bahwa sebagian besar pegawai administrasi perkantoran di UKSW tidak memiliki latar belakang pendidikan administrasi perkantoran/kesekretarisan.

Sedangkan uji hipotesis penelitian menunjukkan bahwa terdapat perbedaan kompetensi pegawai administrasi perkantoran secara signifikan dalam kategori pegawai yang memiliki bidang studi administrasi perkantoran/kesekretarisan dan kategori pegawai yang tidak memiliki bidang studi administrasi perkantoran/kesekretarisan. 


\section{Perbedaan Kompetensi Pegawai Administrasi Perkantoran Dalam Kategori Keterlibatan dalam Pelatihan/Training}

Seperti yang telah dibahas dalam kerangka teori, pelatihan lebih berkaitan dengan peningkatan keterampilan karyawan yang sudah menduduki suatu pekerjaan atau tugas tertentu sehingga lebih menekankan pada keterampilan (skill). Pelatihan merupakan cara terpadu yang diorientasikan pada tuntutan kerja aktual, dengan penekanan pada pengembangan skill, knowledge dan ability. Pendapat yang senada disampaikan oleh Mangkuprawira (2003), yang mengukapkan bahwa pelatihan merupakan sebuah proses mengajarkan pengetahuan dan keahlian tertentu serta sikap agar karyawan semakin terampil dan mampu melaksanakan tanggungjawabnya dengan semakin baik, sesuai dengan standar. Lebih lanjut diungkapkan bahwa pelatihan merujuk pada pengembangan keterampilan bekerja (vocational) yang dapat digunakan dengan segera. Dalam studi Hamilton (2008), tingkat kinerja karyawan dapat ditentukan oleh jenis pelatihan dan pengembangan karyawan yang pernah diikutinya dan tingkat kompetensi meningkat sebagai akibat secara langsung atau tidak langsung hasil dari pelatihan dan proses pengembangan. Lebih lanjut dikatakan bahwa organisasi harus merancang program pelatihan dan pengembangan yang meningkatkan kinerja dengan memfokuskan pelatihan tersebut dan program pengembangan kompetensi, pelatihan untuk pengembangan jangka panjang.

Pendidikan dan juga pelatihan secara parsial telah terbukti berhubungan dengan usaha-usaha berencana yang diselenggarakan untuk mencapai penguasaan skill, pengetahuan dan sikap-sikap pegawai atau anggota organisasi dalam hal ini pegawai administrasi perkantoran. Pendidikan dan pelatihan adalah suatu proses yang akan menghasilkan suatu perubahan perilaku peserta yang berbentuk peningkatan kemampuan kognitif, afektif ataupun psikomotor.

Pendidikan dan pelatihan merupakan istilah yang berhubungan dengan usahausaha berencana yang diselenggarakan untuk mencapai pemuasan skill, pengetahuan dan sikap-sikap pegawai atau anggota organisasi. Pendidikan dan latihan adalah suatu proses yang akan menghasilkan suatu perubahan perilaku peserta yang berbentuk peningkatan kemampuan kognitif, afektif ataupun psikomotor. Disamping memiliki tujuan yang sama yaitu untuk meningkatkan kompetensi seseorang, pendidikan dan pelatihan memiliki beberapa dimensi perbedaan, Tabel 2 menunjukkan perbedaan antara pendidikan formal dengan program pelatihan.

Dengan pemahaman di atas dapat disimpulkan bahwa pegawai yang pernah mengikuti kegiatan pelatihan profesional diyakini memiliki kompetensi yang lebih baik daripada dengan yang tidak pernah mengikuti pelatihan.Hasil penelitian menunjukkan bahwa sebanyak 45 orang pegawai atau 75 persen tidak pernah mengikuti program pelatihan profesi dalam tiga tahun terakhir. Sedangkan sebanyak 15 orang telah mengikuti program pelatihan. Dengan demikian dapat dikatakan 
bahwa sebagian besar pegawai administrasi perkantoran pada UKSW tidak pernah mengikuti program pelatihan profesi dalam tiga tahun terakhir.

Tabel 2

Perbedaan antara Pendidikan Formal dengan Program Pelatihan

\begin{tabular}{lll}
\hline \multicolumn{1}{c}{ DIMENSI } & \multicolumn{1}{c}{ PENDIDIKAN } & \multicolumn{1}{c}{ PELATIHAN } \\
\hline Pengembangan kemampuan & Menyeluruh (overall) & Khusus (spesifik) \\
Area kemampuan (penekanan) & Kognitif,afektif, & Psikomotorik \\
& psikomotorik & \\
Jangka waktu pelaksanaan & Panjang & Pendek \\
Materi yang diberikan & Lebih umum & Lebih khusus \\
Metoda belajar & Konvensional & Inkovensional \\
Penghargaan akhir proses & Gelar (degree) & Sertifikat \\
\hline
\end{tabular}

Sumber: Notoadmojo, dalam Samsudin (2003)

Dari hasil uji hipotesis, menunjukkan bahwa terdapat perbedaan kompetensi pegawai administrasi perkantoran secara signifikan dalam kategori pegawai administrasi perkantoran tidak pernah mengikuti pelatihan dan kategori pegawai yang pernah mengikuti pelatihan, dengan tingkat kepercayaan 95 persen. Dengan demikian dapat dikatakan bahwa pegawai yang mengikuti program pelatihan memiliki kompetensi yang lebih baik dari pada pegawai yang tidak pernah mengikuti program pelatihan.

\section{Pengaruh Kompetensi terhadap Kinerja Pegawai Administrasi Perkantoran}

Kinerja yang baik dari karyawan merupakan harapan bagi setiap organisasi. Dengan memiliki karyawan yang memiliki kinerja yang baik, maka sebuah organisasi dapat dengan mudah mencapai tujuan yang telah ditetapkan. Kinerja yang optimal dari suatu fungsi dalam perusahaan sangat ditentukan oleh karakteristik dan kualitas sumber daya manusia yang terlibat didalamnya. Selain itu juga bergantung pada karakteristik organisasinya. Dengan demikian karakteristik organisasi, karakteristik sumber daya manusia dan kinerja pelaksanaan fungsi-fungsi organisasi merupakan hal-hal yang saling berkaitan.

Mangkunegara (2002) menyatakan bahwa salah satu faktor yang memengaruhi kinerja seseorang yaitu kemampuan yang terdiri dari kemampuan potensi dan kemampuan realitas (knowledge dan skill). Menurut Chetam and Chivers (1996), kompetensi beserta berbagai komponen penyusunnya akan berinteraksi sedemikian rupa yang kemudian akan menghasilkan kinerja yang spesifik.

Dalam penelitian ini telah diajukan hipotesis lima untuk mengetahui pengaruh kompetensi pegawai administrasi perkantoran terhadap kinerja mereka. Sehubungan dengan hal tersebut, hasil penelitian yang diperoleh menunjukkan bahwa memang terdapat pengaruh kompetensi pegawai administrasi perkantoran 
secara signifikan terhadap kinerja pegawai administrasi perkantoran. Dengan demikian hasil penelitian ini mendukung penelitian terdahulu bahwa terdapat hubungan antara tingkat kompetensi dengan kinerja karyawan.

Karena kompetensi individu dalam hal ini pegawai administrasi perkantoran memiliki pengaruh yang kuat terdapat kinerjanya, maka perlu diperhatikan tentang kompetensi pegawai administrasi perkantoran yang bekerja pada setiap organisasi. Pentingnya peran pegawai administrasi perkantoran dalam membantu tugas pimpinan organisasi, menjadi alasan yang kuat untuk memperhatikan kinerja mereka sehingga efektifitas pelayanan informasi dan administrasi perkantoran benar-benar terwujud berkat bantuan dari para pegawai administrasi perkantoran.

\section{SIMPULAN DAN SARAN}

\section{Simpulan}

1. Tidak terdapat hubungan yang signifikan antara jenjang/tingkat pendidikan dengan kompetensi pegawai.

2. Terdapat hubungan antara pengalaman kerja dengan kompetensi, namun kadar hubungan kedua variabel menunjukkan hubungan yang lemah dan terdapat kecenderungan semakin tinggi pengalaman kerja akan semakin tinggi pula tingkat kompetensi para pegawai.

3. Terdapat perbedaan signifikan atas kompetensi antara pegawai yang memiliki bidang studi administrasi perkantoran/kesekretarisan dengan pegawai yang tidak memiliki bidang studi administrasi perkantoran/kesekretarisan.Pegawai yang memiliki latar belakang administrasi/kesekretarisan memiliki kompetensi yang lebih baik daripada pegawai yang tidak memiliki latar belakang administrasi/kesekretarisan.

4. Terdapat perbedaan signifikanatas kompetensi antara pegawai yang mengikuti pelatihan dengan pegawai yang tidak mengikuti pelatihan.Pegawai yang mengikuti program pelatihan memiliki kompetensi yang lebih baik daripada pegawai yang tidak pernah mengikuti program pelatihan.

5. Terdapat pengaruh secara signifikan antara kompetensiterhadap kinerja.

\section{Saran}

1. Pengembangan SDMmelalui studi lanjut pada pendidikan formal kurang tepat diterapkan bagi para pegawai fungsional administrasi perkantoran. Program pengembangan SDM melalui peningkatan pendidikan formal, lebih baik diterapkan untuk mempersiapkan SDM dalam fungsi manajerial.

2. Sistem penerimaan pegawai baru lebih mengutamakan pegawai yang telah memiliki pengalaman kerja yang relevan yaitu sebagai staf administrasi perkantoran. Hal ini untuk memperoleh pegawai yang memiliki kompetensi yang lebih baik. 
3. Dalam sistem penerimaan pegawai baru (rekrutmen) khususnya untuk fungsi administrasi perkantoran, hendaknya memberikan persyaratan atau kualifikasi calon pegawai yang memiliki latar belakang pendidikan (bidang studi) yang relevan yaitu bidang studi administrasi perkantoran/kesekretarisan dalam berbagai jenjang. Hal ini diperlukan agar bisa mendapatkan pegawai yang benar-benar berkompeten dalam bidang administrasi perkantoran.

4. Program pelatihan administrasi perkantoran dan kesekretarisan sangat diperlukan bagi para pegawai untuk meningkatkan kompetensi kerja mereka. Terlebih dari temuan menunjukkan bahwa sebagaian besar pegawai administrasi di UKSW tidak pernah mengikuti program pelatihan dalam tiga tahun terakhir.

5. Manajemen SDM UKSW lebih memperhatikan serta mengembangkan kompetensi kerja pegawai administrasi perkantoran, agar para pegawai dapat mencapai kinerja yang optimal. Standarisasi kompetensi pegawai administrasi perkantoran UKSW sangat diperlukan, mengingat sangat bervariasinya profil para pegawai yang meliputi perbedaan latar belakang pendidikan, jenjang pendidikan, pengalaman kerja, serta keterlibatan dalam program pelatihan. Standarisasi kompetensi dapat dilakukan melalui program sertifikasi kompetensi yang bisa dilakukan dengan bantuan Lembaga Sertifikasi Profesi (LSP) yang telah ada, khususnya LSP administrasi perkantoran dan kesekretarisan, yang dibawah naungan Badan Nasional Sertifikasi Profesi (BNSP). Melalui proses sertifikasi profesi, para pegawai administrasi perkantoran akan memiliki standar kompetensi yang jelas. Sedangkan bagi manajemen SDM UKSW, sertifikasi profesi dapat dijadikan acuan/dasar untuk pertimbangan program peningkatan kesejahteraan para pegawai, khususnya pegawai administrasi perkantoran.

\section{DAFTAR PUSTAKA}

Achadiyati,S. 2006.Analisis pengaruh orientasi pembelajaran dan motivasi berprestasi terhadap kompetensi karyawan serta implikasinya terhadap peningkatan kinerja karyawan (studi kasus pada dinas peternakan Provinsi Jawa Tengah).Availabel at:http://www.unissula.ac.id/show.php?.

Armstrong, M. 1998. Performance Management. England: Clays Ltd. St Ives Ple.

As'ad. 1995. Psikologi Industri. Edisi kedua. Yogyakarta: Penerbit Liberty.

Boulter, N., M. Dalziel., dan J. Hill. 1996. People and Competencies, London:Bidlles, Ltd.

Carter, L. 2011. The relationship between interpersonal relational competence and employeeperformance: Adevelopmental model. International Journal of Interdisciplinary Social Sciences. Vol.6No.3: 217.

Chetam,G.,dan C. Chivers. 1996. Toward a holistic model of professional competence. Journal of European Industrial Training Vol.20 No.5:20-30. 
Fitriyadi. 2002. Pengaruh kompetensi keterampilan, pengetahuan dan kecakapan dalampengembangan sumber daya manusia terhadap kinerja aparatur PD bangun banua Propinsi Kalimantan Selatan.Thesis. Post Graduate Airlangga University. Availabel at:http://Adln.Lib.Unair.Ac.Id/ Go.Php?.

Gibson, J., J. M. Invancevich, Donnelly Jr., dan R. Konopaske. 2003. OrganizationsBehavior, Structure, Processes.New York: McGraw-Hill Company.

Hamilton, D. I.,dan A. O.Oparanma. 2008. Training, development and employeeperformance in the oil and gas industry in Nigeria. European Journal of Scientific Research. Vol.19 Issue 3: 518.

Republik Indonesia. 2002. Keputusan Menteri Pendidikan Nasional No.045/U/2002, tentang Kurikulum Inti Pendidikan Tinggi.

Republik Indonesia. 2007. Standar Kompetensi Kerja Nasional Indonesia (SKKNI) Sektor Jasa Bidang Jasa Administrasi Perkantoran Perkantoran.

Novitasari, N. N. 2003. Pengaruh stress kerja terhadap motivasi kerja dan kinerja karyawan PT HM Sampurna Surabaya, Thesis, Program Pascasarjana Universitas Airlangga Surabaya. Available at:www.damandiri.or.id.

Mangkunegara, A. P. 2002. Manajemen Sumber Daya Manusia Perusahaan. Bandung: PT Remaja Rosdakarya.

Mangkuprawira,Tb. S.2003. Manajemen Sumber Daya Manusia Strategik, Jakarta: Ghalia Indonesia.

Mathis, R. L., dan J. H. Jackson. 2006. Human Resource Management, Alih Bahasa. Jakarta: Salemba Empat.

Palan, R. 2007. Competency Management, Teknik Mengimplementasikan Manajemen SDM Berbasis Kompetensi untuk Meningkatkan Daya Saing Organisasi. Jakarta: Penerbit PPM.

Prawirosentono, S. 1999. Kebijakan Kinerja Karyawan. Yogyakarta:BPFE.

Robbins, S. P. 2001. Organizational Behavior. Ninth Edition. New Jersey: PrenticeHall,Inc.

Robotham dan R. Jubb. 1996. Competences measuring the unmeasurable. Management Development Review Vol.9 No.5: 25-29.

Rosidah. 2003. Pengaruh kompetensi sumber daya manusia terhadap kinerja PT Cheil Jedang Indonesia di Jombang Jawa Timur. Tesis, Program Pascasarjana Universitas Airlangga Surabaya. Available at:www.damandiri.or.id.

Sanchez. 1997. Competence-Based Strategic Management. London: John William \& Sons.

Samsudin. 2003. Faktor yang memengaruhikinerja kepala desa dalam pelaksanaan tugas pemerintahan desa di Kabupaten Katingan Propinsi Kalimantan Tengah. Tesis, Program Pascasarjana Universitas Airlangga Surabaya. Available at:www.damandiri.or.id.

Simanjuntak, P. J. 2005. Manajemen kinerja.Informasi Hukum. Vol.1.

Suharti, L. 2005. Kompetensi Manajerial. Fakultas Ekonomi. Universitas Kristen Satya Wacana. 
Wirawan. 2009. Evaluasi Kinerja Sumber Daya Manusia, Teori, Aplikasi, dan Penelitian. Jakarta: Salemba Empat.

Tandelilin, E. 2005. Employee empowerment based on competency. Jurnal Manajemen dan Bisnis(Maret). Vol.3 No.1. 